\section{THE NATURAL AND ANTHROPOGENIC LANDFORMS AS HABITATS FOR ENDEMIC PLANT SPECIES Convolvulus persicus L. \\ DANELA STRAT}

Bucharest University, Faculty of Geography, dstrat@geo.unibuc.ro

\section{Abstract.}

On the marine field Sărăturile from Danube Delta, naturally grows an endemic plant, Convolvulus persicus L. (sand bindweed), which uses the Black Sea and Caspian littoral as its exclusive spread area particularly on high beaches and sand dunes. Up until 1970, the Southern marine half of the field Sărăturile was a natural landscape with mobile sands, dunes, ponds, and marshes. Then, for protection of Sf. Gheorghe village against the migration of sands, the Southern half of the field was deeply transformed by afforestation and, thereby, the natural evolution of the landscape was disturbed. The impact of anthropogenic processes was simply the appearance of a new, human made, relief. This took the following forms: levelled land with an almost flat morphology, filled marshs, drained ditches and canals, dredges spoil banks, changed internal arrangement of sediment packages, and truncated soils. Meanwhile, the obvious human impact on coastal landforms has been attenuated by natural and planted vegetation through biogenic processes, which have been changed by aeolian processes that were predominant before.

On some man made landforms, namely dredge spoil banks and levelled land masses, afforested with Eleagnus angustifolia and Hippophaë rhamnoides, located at $2 \mathrm{~km}$ away from the active shore, there are few populations of $\mathrm{C}$. persicus. This fact seems really unwarrantable and unexpected because this plant occurs very scarcely, even on natural habitats. In protected areas - Marine Sand Dune Agigea from the South side of the Western Black Sea littoral, where it was discovered for first time in year 1915- keeping its populations in natural conditions is quite difficult. However, this evidence is a good sign for any practice, which requires in situ or ex situ conservation methods of this rare species of plant life, which has no economic value but is important for a healthy diversity of European flora.

Key words: Convolvulus persicus L., habitats, endemic species, anthropogenic landforms, dredge deposit, dune field

\section{Introduction}

In their natural dynamic state, coastal landform systems are self-sustaining through the processes of sediment erosion and deposition. All coastal landforms have critical characteristics and beneficial functions. If these characteristics are maintained and the landforms function naturally, the coastal landform system is sustained. To maintain their critical characteristics and provide their beneficial functions, coastal landforms must be allowed to erode, migrate, and change in form and volume. This is simply because they are actual habitats for many plant species, some of which are very important for dune stabilisation and coastal protection. Other plants are sometimes rare or even endangered, inculding endemics.

Numerous human activities have contributed directly or indirectly to the loss and alteration of biodiversity at local, regional and global scales. Rare and endemic plant species were the first to be threatened. Human influence at a local scale include such activities that directly modify or destroy coastal sand natural habitats such as dredging, spoil dumping, grid ditching, canals cutting and sand mining. The afforestation of mobile sand fields and coastal dunes for their stabilisation is a widespread practice in many coastal areas. In this case plants are deliberately used to be biogeomorphologic agents [12].

The Sărăturile marine field (part of Danube Delta) is a very young land, about 2000 years old [7]. The natural environment - annual amount of rainfall and soils - does not allow development of wild forest ecosystems, but many herbaceous plant species occur sparsely; some 
of them are rare for Romanian flora. One of them is Convolvulus persicus or the sand bindweed.

\section{The environment of study area}

The research was carried out in the Sărăturile marine field. It is located South-East of Danube Delta, on the North side of Sf. Gheorghe arm of the Danube River (Fig. 1). It has a triangular shape, and is sided to the East by the Black Sea, while being passed by parallel $45^{\circ}$ North latitude. The only human settlement - Sf. Gheorghe village - with about 970 inhabitants, was established on the left hand side of river's bank, $3 \mathrm{kms}$ away from the Black Sea shore. The main activity of the population in the study area is traditionally fishing, but in the last decade, ecotourism represents a second main activity.

From the geomorphological point of view, Sărăturile marine field is part of high marine deltaic plain [23]. In fact, it is a large beach ridge plain that formed largely during the late - Holocene when Sf. Gheorghe II deltaic lobe developed $[6,7]$, by successive joints of many spit bariers.

During the $19^{\text {th }}$ century and the first half of the $20^{\text {th }}$ century, the Sf. Gheorghe beach prograded continuously leaving behind a dune field which had gradually been transformed into a deflation plain with small dunes, saline slacks and swamp areas [24]. The altitude of the marine field ranges from $-0.5 \mathrm{~m}$ to $2 \mathrm{~m}$, with most of its surface parts having altitudes ranging from 0 to $1 \mathrm{~m}$ above sea level [23].

The present coastline of the Sărăturile appears generally straight or only slightly curved, and without any prominent headlands. The shore deltaic Sărăturile is a $30 \mathrm{~km}$ long straight shore North - South oriented. The half-South shore that is about $5 \mathrm{~km}$, named Sf. Gheorghe, has a longitudinal dune system with a very large sandy beach.
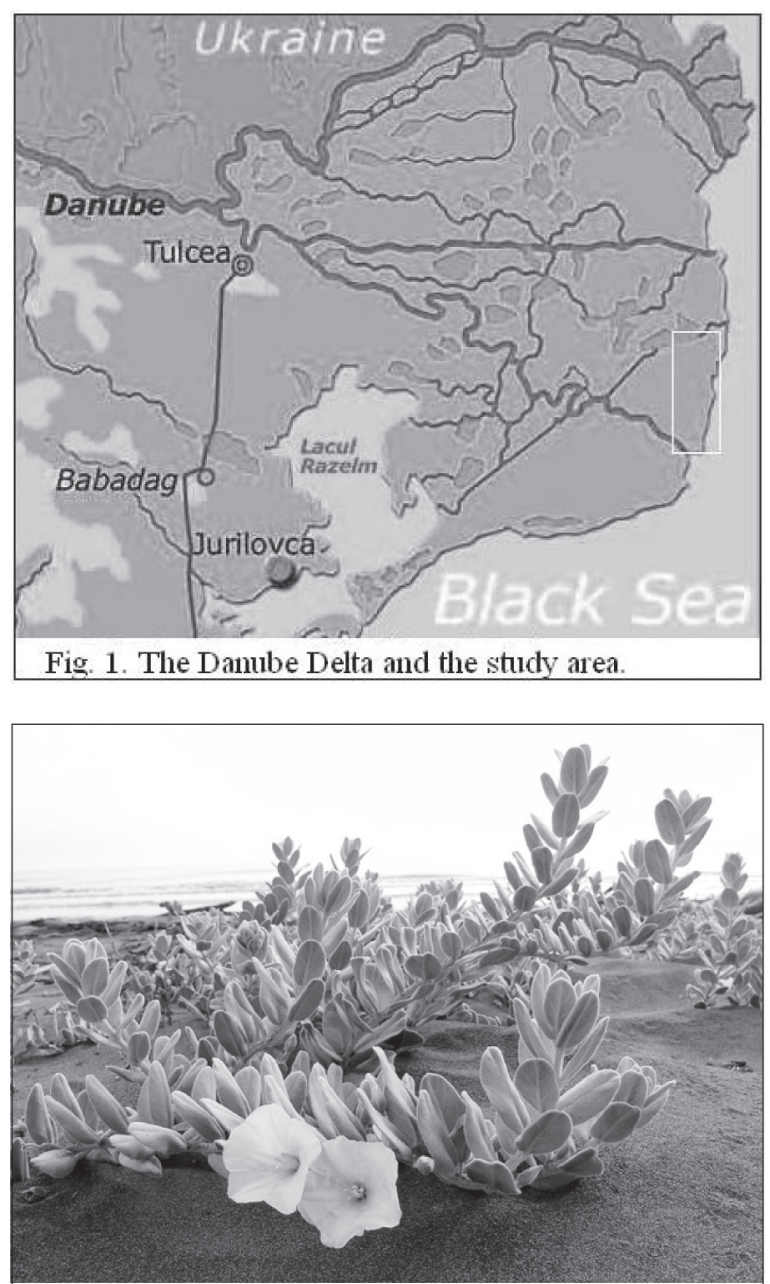

Fig. 2. Convolvulus persicus $\mathrm{L}$. on the beach 
This shore is characterized by a rapidly advancing shoreline, brackish water, and a microtidal environment. The tide is only $15 \mathrm{~cm}$ at its maximum. On this shore, there are large populations of C. persicus.

The study area is a semi-arid territory with hot and dry summers and cold winters. Climate is typically continental and temperate, with Pontic influences (hot summers and severe winters). Annual mean temperature is $11.3^{\circ} \mathrm{C}$. In other words, while this area's maximum mean temperature in the warmest month of July is $21.2^{\circ} \mathrm{C}$, its minimum counterpart in the coldest month of January is $1^{\circ} \mathrm{C}$. Annual precipitation averages $396,1 \mathrm{~mm}$, distributed unevenly along the year, but often decreases below 350 $\mathrm{mm}$. The peak in the mean annual rainfall is recorded in June. Because of high summer temperatures, which partiallycontrols the rate of evaporation in this space, evaporation exceeds precipitation. During the vegetation period, April-September, the climatic characteristic features are: rainfall amount below $200 \mathrm{~mm}$, temperature above $18^{\circ} \mathrm{C}$ and De Martonne aridity index 16.3 [4]. However, the real aridity index in the atmospheric layer, which is very close to sand surfaces where plants live, is below 10 . The temperature of the air immediately above bare sands rises in the summer months to almost $60^{\circ} \mathrm{C}$. In the summer month of July, the differences between midday temperature of $20 \mathrm{~cm}$, and $150 \mathrm{~cm}$ above ground, range from 13.7 to $15.4^{\circ} \mathrm{C}$. All of these parameters suggest a semi-arid climate. The number of droughty days, which are calculated using Walter-Leith criteria, is 104 [2]. A comparative analysis of climatic parameters from the 1969-1996 and 2000-2004 periods reveals the increasing of the aridity of the area after year 2000 because it recorded a longer dry and drought interval and a shorter moist interval than before [1].

The geological substrate is made up of sand, mud and clay deposits [7]. The entisols and psamosols were developed on the youngest fluvio-marine sands. The coarse sand fraction (the median grain-size varies in the range $0.2-2 \mathrm{~mm}$ ) is around $60 \%$ [11]. Because these soils have low clay content, $<3 \%$ [11], and large pores size, most rain water gets lost by the effect of infiltration. Observations revealed that in July, the humidity from the first $20 \mathrm{~cm}$ is just $5.25 \%$ from dry weight and in August and September soils are, practically, completely dry [11]. Progressively, colonizing species are in the gradual process of soil development through litter fall and the built-up of organic matter, soil organisms and micro flora.

\section{Convolvulus persicus $L$. and its natural habitats}

The study area is in a natural state and preserves a rich flora with a high number of native vascular plants [19]. Moreover, some of them are rare or endemic flora like C. persicus. Why is C. persicus an endemic plant? According to Taylor (1916), quoted by Fairbrothers [22, 5],,endemic species are those restricted to very small areas and are examples of geographical isolation and range limitation. C. persicus is a rare species from Romanian flora, critically endangered, according with Threatened Plant Committee and World Conservation Union (IUCN) classifications [20], because it has discontinuous habitats with small populations and its habitats have a high degree of particularity - the fluviomarine sands.

In fact C. persicus is a Pontic-Caspian endemic, because it grows in very specific habitats - high beaches and sand dunes - and has a small geographic range: sandy littoral area of Caspian Sea and Black Sea. Because its habitats was mostly distroyed by human activities, today there are only a few populated sites, in protected areas, such as the Danube Delta which is a Biosphere Reservation.

In 1753, the famous Swedish botanist, C. Linné, named this palnt - persicus - after the place of its origins - Caspian Sea coast from Persia, and was first to provide information about its habitat- sand dunes [9]. One of earliest written mentions, regarding the presence of $\mathrm{C}$. persicus in the Black Sea coast came from the end of the XVIII century, in a letter from John Sibthorp sent to the English botanist J. E. Smith from Constantinople 
[17]. On the Romanian Black Sea Coast, this plant was discovered at the beginning of the last century on some dunes as from the South Romanian coastal Black Sea [16] and at Sf. Gheorghe [14]. Today, the Romanian Black Sea coast is the only place in Europe where there are big and viable populations of C. persicus and the best location in it is the Sărăturile shore [18]. The landforms of this shore - beaches, fore-dunes, and wash-over fans - are open, windy, and barren habitats.

The fore-dune, the main habitat, reaches about 1-1.5 $\mathrm{m}$ above sea level, and follows the North-South direction of the shoreline. It receives its sand from the gently sloping beach, which is $30-50 \mathrm{~m}$ in width. Landward of the fore-dune, there is a gently undulating sand field, where grain-size distribution of material is quite similar to that of the fore-dune, but with slightly more coarse grains.

What is C. persicus? C. persicus is one of the plant species belonging to "morning-glory" family Convolvulaceae. This herbaceous perennial species, typical for Caspian and Pontic coastal habitats, grows only on mobile sands from open places - high beaches, fore dunes, washover fans - which are directly under sea control (waves, sea spray, storms or high speed winds), and on grey coastal dunes. This psamophilous plant species has a very branched rhizomatous stem and a large root system that helps it to maintain its place in shifting sands while gaining access to the water table below. Underground rhizomes may range from $15 \mathrm{~cm}$ to $3,5 \mathrm{~m}$ long, and extensive roots can measure 5,5 m long and penetrate deeply into the sand or sandy soils.

The annual aboveground stem, straight or prostrate with branches, is $20-40 \mathrm{~cm}$ long. It is alternately leaved. Leaves are ovate-elliptical shaped with sub sessile petiole and is about $2-4 \mathrm{~cm}$ long. Its white flowers have five fused petals forming a $2-2.5 \mathrm{~cm}$ long funnel-like corolla, and attach themselves alternately along the stem. It is a very hairy plant, which forms a silvery-green mat on the surface of the sand (Fig. 2).

This species is a pioneer plant adapted to sea spray, accretion (build up of sand), wind blasting and dehydration, high solar radiation, storms, and even wave attack. It is an important biogeomorphological agent because of its root capacity and rhizome systems for binding the sand surface, as a results of ecological conditions. Vegetative reproduction through the rhizome is very effective, and after burial in sand it can form adventitious roots and negative geotropic roots extending into the new sand layers. The plant not only tolerates burial in sand, but demands it in order to retain its vitality, so that its growth follows the annual accumulation of sand. In some spots in its habitats, there are patches of the continuouse carpets of aboveground stems. These stems reduce the power of the winds, limit aeolian processes, shelter ground surfaces and trap sand grains. As a result, sand accretion is stimulated. In the summer season, this plant species binds shields-like embryo dunes on the beach and on the windward slopes of fore-dunes.

\section{The anthropogenic habitats of Convolvulus Persicus $L$.}

Until 1970, Sărăturile marine field was originally treeless [13]. It was a big challenge, therefore, to make forestry in this place. With definite previous failures, the coastal sands of Sf. Gheorghe were considered virtually non-plantable [15]. Generally speaking, afforestation work is considered an "ecological restoration", which means the reestablishment of the type of forest specific to the local soil and climatic conditions. Local tree species and provenances were used for this action [3]. In this case, strictly speaking, planting trees was not simply an ecological restoration, but rather a complete reshaping of the natural landscape. Thus, a large field with mobile sands and bare sand dunes, completely out of woody vegetations with very poor herbaceous vegetation looking like a baren desert landscape [4], have become an area with forests and vegetated dunes. Nevertheless, before that, technical works had to be done 
in order to mechanically change natural landforms and soils. Besides, the planted species themselves could be seen as physical ecosystem engineers. According to Jones and Wright $[8,25]$, there are organisms that directly or indirectly modulate the availability of resources to other species, by causing physical state changes in biotic or abiotic materials. They affect other organisms by creating, modifying, maintaining or destroying habitats.

The major aims of afforestation of the Sărăturile field were to protect Sf. Gheorghe village against moving sands, to ameliorate harsh environment by providing trees for shade and shelter, to mitigate the extreme desiccation during strong winds, to act as windbreaks against dominant North winds, and to trap sand and dust [4] away from the human habitates. There were no concerns about loss of native and rare plants species but, surprisingly, the anthropogenic landforms that resulted at the beginning of forestry works provided habitats for sand bindweed.

Big dredged canals were excavated to collect all waters from dredging. On both sides of the canals, dredge spoil banks have been made, about $2 \mathrm{~m}$ above ground. They were made out of unconsolidated, randomly mixed sediments composed of sand, soil, and shell materials extracted and deposited during dredging and dumping activities. The surfaces between the canals were leveled and ploughed, resulting in sandy substrates with an almost flat morphology.

The flat surfaces with mobile sand and dredged spoil banks are the anthropogenic landforms that have similar features and shapes to the shore natural landforms: beaches and sand dunes. They have been naturally colonized by C. persicus. After almost 40 years, only dredge spoil banks are noticeable in the landscape. The planted nonnative species - Eleagnus angustifolia and Hippophaë rhamnoides - have actually stabilized them. Nowadays these anthropogenic landforms are comparable with grey dunes.

Because of dense woody vegetations, populations of $\mathrm{C}$. persicus are in decline and individuals show phenotypic response. Based on our own observation, C. persicus shows significant variations in morphological traits under different environmental regimes: humidity, salinity, windiness. The plasticity to shading includes an increase in leaf area and stem length, and a decrease in the number of branches and flowers.

\section{Conclusions}

In the Sărăturile marine field from Danube Delta, there are natural and anthropogenic habitats of C. persicus. The proper native habitats are sandy shore landforms, especially foredune. Unexpectedly, sand bindweed colonized anthropogenic landforms inside of the marine field - flat sandy surfaces and dredge spoil banks, which were almost similar with natural habitats of sea shore. Now, the populations of C. persicus in anthropogenic habitats are on the wane because mobile sands from these landforms are stabilized by woody vegetation and because of fast ecological succession. Although it was not a planned experiment for the monitoring of ecological behaviour of C. persicus, this fact is useful for future approaches in situ conservations techniques on the one hand, and in ex situ conservation techniques, on the other.

\section{Acknowledgements}

This research was funded by National University Research Council from Romania through GR. 1661/2007-2008 and by Fluvial and Marine Research Station „Sf. Gheorghe” of Bucharest University. 


\section{References}

1. Bandoc, G., Strat, D., Analyses of some climatic indicators used in monitoring phytocenosys of Sfântu Gheorghe Delta Shore, Analele Universității OVIDIUS, Seria Geografie, 3, 2007, pp. 1004-1010.

2. Barbu, I., Popa, I., Monitoringul secetei în pădurile din România, Editura Tehnică Silvică Stațiunea Experimentală de Cultură a Molidului, Câmpulung - Moldovenesc, 2003.

3. Byers, J.E., Cuddington, K., Jones, C.G., Talley, T.S., Hastings, A., Lambrinos, J.G., Crooks, Wilson, G.W., Using ecosystem engineers to restore ecological systems, Trends in Ecology and Evolution, Vol. 21 No. 9 (2006), pp. 493-500.

4. Ceuca, G., Bakoş, Măsuri ameliorative în vederea împăduririi grindului fluviomaritim Sărăturile de la Sf. Gheorghe - Deltă, Delta Dunării. Studii şi Comunicări de Entomologie, Vol. 2 (1985), pp. 47-59.

5. Fairbrothers, D.E., Endangered, Threatened, and Rare Vascular Plants of the Pine Barrens and their Biogeography, in Richard T.T. Forman (ed.) Pine Barrens. Ecosystems and Ladscape, Rutgers University Press, New Brunswick, 1988, p. 397.

6. Giosan, L., E. Vespremeanu, J.P. Donnelly, J. Bhattacharya, and F. Buonaiuto, Morphodynamics and evolution of Danube delta. in Giosan and Bhattacharya (Eds.), River Deltas: Concepts, Models, Case Studies, SEPM Special Publication, Vol 83(2005), pp. 391-410.

7. Giosan, L., Filip, F., Constantinescu, Şt., Was the Black Sea catastrophically flooded in the early Holocene?, Quaternary Science Reviews 28, January (2009), pp. 1-6.

8. Jones, Clive G., Lawton, John H., Shachak, Organism as ecosystem engineers, OIKOS 69(1994), pp.373-386.

9. Linnæi, Carola, 1753, Species Plantarum, Exhibentes Plantas Rite Cognitas, ad Genera Relatas,cum Differentiis Specificis, Nominus Trivialibus, Synonymis Selectis, Locis Natalibus, Secundum Systema Sexuale Digestas.Tomus I., Holmiæ, Impensis Laurentii Salvii.

10. Mainguet, M., and Reimer, T.O., Aridity: Droughts and Human Development, Springer, 1999.

11. Mănescu Mihaela, Traci, C., Tehnologii de împădurire a nisipurilor din Delta Dunării, Analele ICAS, Vol. 40(1992), pp. 65-85.

12. Mitchell, Peter, The influences of vegetation, animals and micro-organism on soil processes, in
Heather A. Viles (ed.), Biogeomorphology, Basil Blackwell, Oxford, 1988, pp. 43-82.

13. Muşat, I., Pârvu, E., Ivanschi, T., Leandru, V., Băluică Ioana, Stabilirea soluţiilor de instalare şi întreținere pe nisipurile din zona ,Sf. GheorgheIvancea", Analele ICAS, Vol. 37 (1), 1980, pp. 111-128.

14. Negrean, G., Dihoru, G., Flora of Danube Delta, in Gavrilă Simion, Maria Popescu, Anina Jecu (eds.), [16] Peuce, Vol. V, Botanica, Muzeul Delta Dunării, Tulcea, 1976, pp. 217-252.

15. Purcăreanu, Gh. N., Cărare, O. Studiul perspectivelor dezvoltării gospodăririi silvice în Delta Dunării, Analele ICAS, Vol. 16 (2), 1956, pp. 131-168.

16. Săvulescu, T., Convolvulus persicus L. en Roumanie, Bull. Sect. Scient. Ac. Roumaine, IV, 2, 1915/1916, pp. 69-70.

17. Smith, J. E., Memoir and Correspondence of the Late Sir James Edward, Vol. I, London, 1832.

18. Strat D., Răspândirea geografică şi habitatele speciei Convolvulus persicus în contextul strategiei europene de conservare a biodiversității, in Floare Grecu (ed), Comunicări de Geografie, vol. XII, Editura Universităţii din Bucureşt, (2008), pp. 125-130.

19. Strat, D., Flora of marine field Sărăturile, Studii şi Cercetări de Oceanografie Costieră, II (2008), in the press.

20. Taina, Şt., Specii reprezentative pentru evaluarea biodiversității floristice din România, in D. Davidescu (ed.) Conservarea biodiversității speciilor vegetale și animale, Editura Academiei Române, Bucureşti, 2002, pp.75-88.

21. Traci, C., Ceuca G., Catrina I. et al. Dezvoltarea şi întreținerea culturilor forestiere pe nisipurile fluvio-marine de la Sf. Gheorghe din Delta Dunării, I.C.A.S., Seria a II -a (1982), pp. 82112.

22. Taylor, N., Endemism in flora of vicinity of New York, Torreya, 16 (1916), 18-27.

23. Vespremeanu, E., Vespremeanu-Stroe, A., Constantinescu, $\square$ t., Evoluția țărmului Deltei Dunării în ultimii 40 ani, Studii şi Cercetări de Oceanografie Costieră, Vol. I (2004), pp. 15-30.

24. Vespremeanu, E., Morfologia reliefului Deltei Dunării în ultimii 40 ani, Studii şi Cercetări de Oceanografie Costieră, Vol. I (2004), pp. 31-60.

25. Wright, Justin P., Jones, Clive G., The Concept of Organism as Ecosystem Engineers Ten Years on: Progress, Limitations, and Challenges, BioScience, Vol. 56, No. 3, March (2006), pp.203-209. 